\title{
Alta dose de ciclofosfamida seguida por transplante autólogo de medula óssea, é segura e eficaz como terapia de salvamento em linfomas agressivos e na doença de Hodgkin quimiosensíveis
}

High-dose cyclosphamide followed by bone marrow transplant is safe and efficient to treat chemo-sensitive patients with aggressive lymphoma and Hodgkin's disease

Renata B. Cardoso

\section{Orientador:}

Cármino A. de Souza

\section{Resumo}

Uma grande proporção dos pacientes com Doença de Hodgkin e Linfoma não-Hodgkin recidivará ou não atingirá remissão completa com quimioterapia inicial. O manuseio destes pacientes é usualmente desapontador e a taxa de sobrevida a longo prazo, é inferior a 10\%. Resultados de várias séries têm demonstrado que, terapia de alta dose seguida por transplante autólogo de medula óssea ou células progenitoras periféricas, pode conseguir melhores taxas de sobrevida livre de doença, a longo prazo, em uma proporção substancial de pacientes. Alta dose de CY, seguida por fatores de crescimento hematopoiéticos, é o regime mais amplamente utilizado para mobilização e coleta de células progenitoras periféricas. O principal objetivo deste estudo prospectivo, foi demonstrar o papel da alta dose de ciclofosfamida em reduzir o crescimento tumoral e promover eficiente mobilização de células CD34+. Além disso, determinar a efetividade da alta dose de CY + VP-16 (+/-MTX na DH), seguida por autotransplante, como terapia de salvamento em pacientes portadores de doença recidivada ou persistente.

A partir de 1997 a 2000, 35 pacientes com mediana de idade de 33 anos, portadores de
LNH (60\%) ou DH (40\%) recidivados ou refratários, submeteram-se a tratamento com terapia de escalonamento de dose (CY+ VP-16+/- MTX), seguido por transplante autólogo de células progenitoras periféricas. De acordo com a intenção de tratar, 35 pacientes foram evoluídos. A mediana global de seguimento foi de 574 dias. 33 pacientes (94.2\%) foram submetidos à megaterapia seqüencial e autotransplante com CPP. Estes, receberam uma mediana de $6.42 \times 10^{6} / \mathrm{kg}$ de células CD34+. Os pacientes quimiossensíveis $(n=25)$ e quimiorresistentes $(n=10)$ apresentaram taxas de sobrevida global de $96 \%$ e $15 \%$, respectivamente $(P=0.0005)$, à ciclofosfamida. As taxas de $S G$, ao autotransplante, foram de $92 \%$ para os pacientes quimiossensíveis e $0 \%$, para os pacientes quimiorresistentes $(P=0.0005)$. Mortalidade relacionada à ciclofosfamida foi de 6.5\%. A mortalidade relacionada ao autotransplante foi de $6.0 \%$.

Os resultados são semelhantes e comparam-se favoravelmente à literatura. Alta dose de CY, seguida por megaterapia seqüencial e autotransplante, mostrou ser efetiva e segura, como terapêutica de salvamento em pacientes portadores de LNH a $\mathrm{DH}$, agressivos, com aceitável mortalidade relacionada ao procedimento.

Tese apresentada ao curso de Pós-Graduação, da Faculdade de Ciências Médicas, da Universidade Estadual de Campinas para obtenção do Título de Mestre em Clínica Médica 


\section{Abstract}

A substantial proportion of patients with Hodgkin's Disease (HD) and Non-Hodgkin Lymphoma (NHL) will relapse or fail to attain a complete remission with initial chemotherapy. The management of patients with refractory or relapsing $H D$ or $N H L$ is usually disappointing and the long-term survival rate is less than 10\%. Results of several works demonstrated that high dose therapy followed by ABMT or PBSCT can yield long-term disease-free survival in a substantial proportion of patients, with low transplant-related mortality. High-dose cyclophosphamide (HDCY) followed by growth factors is the most widely used chemotherapy for the collection of Peripheral Blood Progenitor Cells (PBPCS). The aim of this study, a nonrandomised clinical trial prospective analysis, was to demonstrate the role HDCY in reducing tumour burden, promoting efficient mobilisation of $\mathrm{CD} 34^{+}$and also determining the effectiveness of HDCY followed by high doses of $V P-16$ and MTX with PBPC autografting as salvage treatment for these patients.

From 1997 to 2000, 35 patients with median age of 33 years (15-65) affected by aggressive NHL (60\%) or by HD (40\%) persistent or relapsed disease, were enrolled and treated using bigh dose escalation (HDCY plus HDVP-
16 plus/minus HDMTX) followed by autologous PBPC Transplantation.

According to "Intention to Treat" basis, 35 patients affected by malignant lymphomas were evaluated. The overall median follow-up was 574 days. 33 patients (94.2\%) underwent PBPC autografting and received a median of $6.42 \times 10^{6} / \mathrm{Kg}$ (1.07 29.3) of $\mathrm{CD}_{34^{+}}$cells. chemosensitive patients $(n=25)$ and chemoresistant patients $(n=10)$ at HDCY presented overall survival of $96 \%$ and $15 \%$, respectively $(P=0.0005)$. Overall survival was 92\% for chemosensitive and $0 \%$ for still chemoresistant patients before transplantation $(P=0.0005)$. Mortality was $6.0 \%$ (two patients) related to HDCY and two (6.5\%) transplantrelated.

These results are similar to those reported in the literature. HDCY $+V P-16$ and MTX (HD) followed by autologous PBPC transplantation showed to be effective and safe as salvage treatment in chemosensitive patients affected by aggressive NHL and $H D$, with acceptable mortality related-sequential treatment.

Recebido: 15/06/01

Aceito: 30/07/01 